told me that she had had a sensation of impending death.

I treated this particular episode with an intramuscular injection of chlorpromazine and she was perfectly normal and rational the next morning. Needless to say, she was not given any more pentazocine.

It is worth noting this particular side effect which was pointed out in your account of this drug (16 May, 1970, p. 409). It is extremely rare and pentazocine is an otherwise excellent analgesic, which we have used fairly extensively in this hospital and with good results. It provides an effective analgesic stronger than codeine but less likely to cause addiction and respiratory depression than morphia.-I am, etc., Shanta Bhawan Hospital,
Katmandu, Nepal

W. M. GouLD

\section{Spontaneous Fractures of Pelvis in Rheumatoid Arthritis}

SIR,-Dr. R. T. Taylor and others (11 December, p. 663) stressed the importance of recognition of spontaneous fractures of pelvis in rheumatoid arthritis. We feel, however, that not only the recognition of these fractures should be stressed, but also the search for the aetiology. The following case history illustrates this point.

A 62-year-old woman with a history of classical rheumatoid arthritis for 22 years was recently admitted for treatment of exacerbation of her disease. Owing to muscle weakness and arthritis of the feet she had been bedridden for several weeks. $X$-ray of the pelvis showed a fracture line in the left iliac bone and right pubic rami. $X$-ray of the ribs revealed fractures with callus on the right tenth and eleventh rib. These fractures were not present on $x$-rays taken one year previously. Details of the biochemical evaluation are given in the Table.

\begin{tabular}{|c|c|}
\hline Serum & $\begin{array}{l}\text { Calcium }(\mathrm{mg} / 100 \mathrm{ml}) 7.6 \\
\text { Phosphorus (mg/100 ml) } 3.9 \\
\text { Alkaline Phosphatase } 2 \text { B.U. }\end{array}$ \\
\hline Urine & $\begin{array}{l}\text { Calcium (mg } / 24 \mathrm{hrs} .) 12.8 \\
\text { Total Hydroxyproline (mg/24 hrs.) } 40 \\
\text { Four-hour Calcium Retention Test } 85 \%\end{array}$ \\
\hline
\end{tabular}

A low serum calcium, calcium-phosphorus product, and urinary calcium excretion, and a high four-hour calcium retention test ${ }^{1}$ were found. Radiological exploration of the gastrointestinal tract revealed no abnormality. Dxylose test, serum cholesterol, and serum carotene were normal. Her home diet was found sufficient for calcium intake, $1.176 \mathrm{mg} /$ day, but deficient for vitamin D, 70 I.U./day.

The histology of an undecalcified bone sample of the iliac crest after double tetracycline labeling revealed: a relative osteoid volume of $10.5 \%$ (normally less than $4 \%$ ) a relative osteoid surface area of $66 \%$ (normally less than $17.5 \%$ ); an osteoid seam thickness of $8.8 \mu$ (normally less than $8.6 \mu$ ), and a lack of a calcification front in some areas. On the basis of radiological, biochemical, and histological evidences the diagnosis of nutritional osteomalacia was made. The nutritional osteomalacia probably was accentuated by a lack of sun irradiation as the patient was house bound, and by a metabolic disturbance due to anticonvulsant drugs given for epilepsy for the past 25 years. 2

Parenteral vitamin $D_{2}$ treatment, $15 \mathrm{mg}$, normalized the biochemical values and raised the serum alkaline phosphatase activity and urinary calcium excretion. Muscle weakness was soon relieved and the patient left the hospital ambulant.

Since four cases out of six $(66 \%)$ in Dr. Taylor and colleagues' series had a low serum calcium, we wonder if these patients were not suffering from osteomalacia rather than from osteoporosis as the authors suggest. In the description by Devas ${ }^{3}$ of 25 cases of stress fractures of the femoral neck no biochemical or histological data are given, which makes us suspect that in that series also many patients might have been suffering from osteomalacia.

Since osteomalacia is a curable disease, all diagnostic techniques have to be used to exclude this aetiology when spontaneous fractures are observed.

We thank Professor F. Meersseman for histological examination.

-We are, etc.,

J. DEQUEKER H. HEYLEN

Rheumatology Unit.

A. Burssens

Academic Hospital Pellenberg (Leuven),

elgium

1 Nordin, B. E. C., and Fraser, R., Lancet, 1956, 2 Dent, C. E., Richens, A., Rowe, D. J. F., and Stamp, T.'C. B., British' Medical fournal, 1970 4,69 .

Devas, M. B., Fournal of Bone and Foint Surgery,
$1965,47 \mathrm{~B}, 728$.

\section{General Practitioner Maternity Units}

SIR,-Dr. J. Oliver Woods (25 December 1971, p. 803) refers to Hobbs and Acheson's finding ${ }^{1}$ that the perinatal mortality in the Oxford area in 1962 was significantly higher in practices with access to the general practitioner maternity units than in practices without access. They concluded that general practitioner maternity units were being used

Chipping Norton Hospital: Perinatal Mortality by Place of Booking and Place of Delivery, 1962-70

\begin{tabular}{|c|c|c|c|c|c|c|c|c|c|c|c|c|}
\hline \multirow{2}{*}{ Year } & \multicolumn{3}{|c|}{$\begin{array}{l}\text { Booked and Delivered in } \\
\text { Chipping Norton } \\
\text { Hospital }\end{array}$} & \multicolumn{3}{|c|}{$\begin{array}{c}\text { Emergency Deliveries in } \\
\text { Chipping Norton } \\
\text { Hospital }\end{array}$} & \multicolumn{3}{|c|}{$\begin{array}{l}\text { Booked for Chipping } \\
\text { Norton Hospital but De- Der Holt } \\
\text { livered in Consultant Unit }\end{array}$} & \multicolumn{3}{|c|}{$\begin{array}{l}\text { All Patients Booked for } \\
\text { Chipping Norton } \\
\text { Hospital }\end{array}$} \\
\hline & $\begin{array}{c}\text { All } \\
\text { Births }\end{array}$ & \begin{tabular}{|c} 
Peri- \\
natal \\
Deaths
\end{tabular} & \begin{tabular}{|c|} 
Perinatal \\
Mortality \\
Ratel \\
1,000
\end{tabular} & Births & $\begin{array}{c}\text { Peri- } \\
\text { natal } \\
\text { Deaths }\end{array}$ & \begin{tabular}{|l|} 
Perinatal \\
Mortality \\
Ratel \\
1,000
\end{tabular} & $\underset{\text { Births }}{\text { All }}$ & $\begin{array}{l}\text { Peri- } \\
\text { natal } \\
\text { Deaths }\end{array}$ & $\begin{array}{l}\text { Perinatal } \\
\text { Mortality } \\
\text { Ratel } \\
1,000\end{array}$ & $\begin{array}{l}\text { All } \\
\text { Births }\end{array}$ & $\begin{array}{c}\text { Peri- } \\
\text { natal } \\
\text { Deaths }\end{array}$ & $\begin{array}{c}\text { Perinatal } \\
\text { Mortality } \\
\text { Ratel } \\
1,000\end{array}$ \\
\hline 1962 & 259 & 7 & 27 & 9 & 0 & 0 & 7 & 1 & 143 & 266 & 8 & 30 \\
\hline 1963 & 259 & 3 & 12 & 8 & 1 & 125 & 16 & 1 & 63 & 275 & 4 & 15 \\
\hline 1964 & 248 & 2 & 8 & 12 & 0 & 0 & 18 & 1 & 56 & 266 & 3 & 11 \\
\hline 1965 & 264 & 1 & 4 & 12 & 1 & 83 & 27 & 4 & 148 & 291 & 5 & 17 \\
\hline 1966 & 282 & 2 & 7 & 13 & 0 & 0 & 17 & 1 & 59 & 299 & 3 & 10 \\
\hline 1967 & 256 & 1 & 4 & 10 & 0 & 0 & 59 & 4 & 68 & 315 & 5 & 16 \\
\hline 1968 & 265 & 2 & 8 & 11 & 0 & 0 & 59 & 4 & 68 & 324 & 6 & 19 \\
\hline 1969 & 260 & 0 & 0 & 8 & 0 & 0 & 51 & 5 & 98 & 311 & 5 & 16 \\
\hline 1970 & 285 & 0 & 0 & 10 & 0 & 0 & 49 & 2 & 41 & 334 & 2 & 6 \\
\hline
\end{tabular}

\section{Motorway Disasters}

SIR,-Dr. J. F. Hindle and his colleagues (1 January, p. 47) refer to the anxiety of the staff of the accident service at the Luton and Dunstable Hospital who go out to deal with multiple crashes on the M1 that they had no insurance cover from their employers in the event of their own injury. They and others whose employment in the Health Service carries special risk asternative to consultant care and not They thought it would be interesting to know whether increasing experience in the selection of cases for delivery in general the situation.

general practitioner maternity unit is some 21 miles from the Nuffield maternity unit at Oxford and 13 miles from the consultant unit at Banbury. As a result of a survey carried out by the doctors in Chipping Norton in 1963 and of the findings of whether the Acheson it was decided to see proved. An Oxford obstetrician agreed to the hospital once a month to see stetricians, firstly to assess their suitability for booking in the unit and, secondly, to monitor cases which had begun to present difficulties. A close and enthusiastic relationship was quickly established between the obstetrician and the general practitioners. The Cranbrook Committee criteria were used as a basis for the selection of cases but, the years have gone by, the rules have sequences.

The Table has been provided by the Oxford Record Linkage Study Group, which has continued to monitor the hospitals in the Oxford Regional Hospital Board area he perinatal mortality rate six in 1970. It will also show a steady reduction in deaths in cases booked for Chipping Norton Hospital but delivered in the consultant unit. I think these figures show what can be done by close co-operation between an obstetrician, general practitioner obstetricians, and midwives, even in a general practitioner maternity hospital distant from a consultant unit.-I am, etc.,

H. M. STEEL

should know that the British Medical Association with the support of the defence organizations has obtained valuable assurances from the Department of Health. They should also know that the Superannuation Bill 1971 now before Parliament empowers the Secretary of State to pay injury allowances to any person engaged in the Health Service, not, as heretofore, solely to those in 